\title{
THE TORTUOUS PATH OF ACCOUNTABILITY TO ENSURE POST-WAR RECONCILIATION-THE CASE OF SRI LANKA
}

\author{
Jehan Perera*
}

\begin{abstract}
For the past three decades Sri Lanka was stalemated between governments that were not prepared to devolve power to the Tamil majority provinces and a Tamil militant movement that wanted a separate country. In February 2002, the Sri Lankan government and LTTE signed a ceasefire agreement under Norwegian government auspices that appeared to offer the real prospect of a final end to violence as a means of conflict resolution. The ceasefire between the government and the LTTE held for nearly four years despite significant problems affecting the peace process, problems that led to the LTTE's withdrawal from the peace talks. However, the ceasefire collapsed in early 2006 with a series of ambushes of government soldiers by the LTTE, eventually leading to counter measures and counter attacks by the forces of the government, measures in which the government wrested back control of territory placed under the control of the LTTE by the terms agreed upon by the Ceasefire Agreement. Today Sri Lanka is a country that continues to be deeply divided on lines of ethnicity, religion and politics. Horizontal inequalities, defined as severe inequalities in economic and political resources between culturally defined groups, were undoubtedly a contributing factor for the perpetuation of Sri Lanka's long-running conflict. No sooner it won the war, the government asserted economic development to be the main engine of reconciliation.
\end{abstract}

Keywords: Ethnic communities, violence, war crimes, governance, darusman report, accountability, human rights, transitional justice, reconciliation

Sri Lanka has a plural society of several different ethnic communities, the two largest being Sinhalese and Tamil which have characteristics of nations with the Muslim community taking third place. The centralized state inherited by the newly independent country in 1948 effectively transferred political power into the hands of the Sinhalese majority who comprise about three fourths of the population. The inability of the political elites belonging to the different ethnic communities to share power equitably among themselves led to a series of broken agreements and to acute mistrust between the communities. The difficulty of protecting minority interests in a unitary system of government in which majority-minority relations are strained is exemplified by Sri Lanka's modern political history. ${ }^{1}$ As the Tamils from the north in particular were rarely represented in the higher rungs of the government, they were unable to sway

\footnotetext{
* Jehan Perera, Ph.D., Executive Director, National Peace Council of Sri Lanka, Colombo

${ }^{1}$ The Sinhalese, though a majority in the nation, feel threatened by the large population of Tamils who surround them in the region. This "minority complex" of the Sinhalese is theorized to contribute to their need for political power (de Silva, K.M.. A History of Sri Lanka. (Colombo: Vijitha Yapa Publications, 2003). p.513.
} 
government decisions to take their concerns into account. The inability of Tamil politicians to obtain adequate redress to their grievances eventually led to the buildup of separatist sentiment, militancy and war.

For the past three decades Sri Lanka was stalemated between governments that were not prepared to devolve power to the Tamil majority provinces and a Tamil militant movement that wanted a separate country. In February 2002, the Sri Lankan government and LTTE signed a ceasefire agreement under Norwegian government auspices that appeared to offer the real prospect of a final end to violence as a means of conflict resolution. The ceasefire between the government and the LTTE held for nearly four years despite significant problems affecting the peace process, problems that led to the LTTE's withdrawal from the peace talks. However, the ceasefire collapsed in early 2006 with a series of ambushes of government soldiers by the LTTE, eventually leading to counter measures and counter attacks by the forces of the government, measures in which the government wrested back control of territory placed under the control of the LTTE by the terms agreed upon by the Ceasefire Agreement.

The Sri Lankan ethnic conflict was considered "one of the deadliest and most protracted conflicts of our time", and was the longest running civil war in the Asian region at the time it ended. The cultural diversity found in Sri Lanka is an essential aspect of both the roots and development of this conflict. The last phase of the war was one of the most challenging in the annals of modern warfare. It ensured that the Sri Lankan war took the headlines of the international media. The LTTE in its retreat herded the Tamil population of the northern territories it once controlled into a tiny patch of land. Using more 300,000 civilians as human shields they sought to keep the Sri Lankan military forces at bay, and buy time for some change to ensure their continued survival. When the LTTE was on the verge of being militarily annihilated the Western countries urged restraint, the non-use of heavy weapons that could cause indiscriminate casualties, and the evacuation of the civilian population.

In May 2009, Sri Lanka's 26-year war between government forces and LTTE came to a bloody end. Sri Lanka is an example where the military response was successful. When a militant organization is unwilling to negotiate and seek an end to violence, the military response will dominate. The more protracted the war, the more turmoil and terrorism is likely to be the outcome. However, the end of the war has left a difficult legacy of human rights violations and war crimes from which the country is trying to extricate itself. Sri Lanka has come under intense international pressure and four resolutions of the UN Human Rights Council in Geneva since 2009 on this account.

Today Sri Lanka is a country that continues to be deeply divided on lines of ethnicity, religion and politics. Horizontal inequalities, defined as severe inequalities in economic and political resources between culturally defined groups, were undoubtedly a contributing factor for the perpetuation of Sri Lanka's long-running conflict. No sooner it won the war, the government asserted economic development to be the main engine of reconciliation. Contrary to hopes that the end of the conflict would lead to democratic

${ }^{2}$ de Votta, Neil. Blowback: Linguistic Nationalism, Institutional Decay, and Ethnic Conflict in Sri Lanka.(Stanford: Stanford University Press, 2004). p.2 
reforms to enable greater devolution of power and accountability, the post-war period became characterized by the shrinking of political space for Sri Lankan civil society, an erosion of the rule of law and increasingly centralized authoritarian rule. If Sri Lanka's success was its ability to annihilate the LTTE on the military battlefield, its failure came with the end of the war and the inability and unwillingness of the victorious government to close the chapter on the war by seeking the truth regarding the past, accountability for war crimes, compensating the victims and engaging in political reform that would heal the wounds of the war, and win the hearts and minds of the people in the war zones. The former government's refusal to take that course of action meant that Sri Lanka risked becoming an international outcaste and the subject of economic and political sanctions that would have generated new divisions and hatreds within the country, and with the international community.

\section{Transition Process}

The over centralization of power during Mahinda Rajapaksa's presidency led to allegations of gross abuse of power, corruption and impunity. The most important features of the Rajapaksa path was the concentration of power in the Presidency, the breakdown of the system of checks and balances which saw the Chief Justice being sacked by the government, even though the Supreme Court and Appeal Court both disagreed with the government, the increasing role of the military in civilian affairs both in the Tamil areas and in the rest of the country, and the growing economic and political dependency on some countries, especially China.

The governance of President Rajapaksa was also marked by non-adherence to systems of governance and by a willingness to obtain results without adequate consideration being given to the costs. His political downfall at these elections was due to excesses that cost him key constituencies. The use of Sinhalese nationalism to an excessive degree alienated the ethnic and religious minorities, especially the Muslims who had voted for the former President at previous elections. But they became subject to physical attacks by extremist Buddhists, who were backed by sections of the government. The level of corruption was also excessive which alienated the Sinhalese intelligentsia, who were concerned about the growing indebtedness of the country.

However, Sri Lanka has been a democracy in which regular elections are an article of faith. The presidential elections of January 2015 offered an opportunity for change. At stake at these elections was whether Sri Lanka continued on the path set by the Rajapaksa government or on a different path. In January 2015 and again in August of the same year the majority of Sri Lankan voters cast their votes against the incumbent government. The main significance of the election verdict is that it paved the way for transition to take place in two key aspects of governance. The first was to take away the arbitrary power of individuals and vest them instead in systems. The sustainability of this process lies in the fact that virtually all the political parties have agreed that the systems of government need to be strengthened. The majority of people chose the Rule of Law over the rule of men that was epitomized by the previous government.

The lifting of the sense of fear in political dissenters and in the ethnic and religious minorities has been the biggest improvement that the change of government brought to 
the country. The new government has charted a shift away from highly centralized and national security-dominant state structure that the Rajapaksa government had constructed to a more consensual mode of governance. In keeping with his election promise, President Maithripala Sirisena with the backing of Prime Minister Wickremesinghe championed the passage of the 19th Amendment to the constitution that reduced the power of the presidency and the scope for the abuse of power and strengthened parliament and state institutions such as the judiciary, public service and police.

The second important transition that the country is taking is away from the continuation of militarization and the rising governmental antipathy towards ethnic minorities of the previous period to a society that is truly multi-ethnic and multi-religious in its decision making and its choices. But as this still remains a transitional process there will need to be a lot of compromise and patience. As the leader of the opposition's election campaign the former president did not appear to learn from the presidential election that he and his allies had to rebuild the trust of the ethnic minorities if they wanted their vote. Instead Rajapaksa and his allies engaged in a strident Sinhalese nationalist campaign that portrayed the ethnic and religious minorities, and their international connections, as threats to the Sinhalese majority. This reinforced the sense of insecurity experienced by the minorities and turned their vote against him once again.

\section{First Challenges}

The first challenge to the President Maithripala Sirisena will be to restore institutions of governance that were undermined during the Rajapaksa period. The system of checks and balances has been eroded. The judiciary and public service became politicized. This has got to be changed. The reliance on individuals is too much to ask of them. The system itself must be strong. Strengthening the system of checks and balances should not be difficult, as all parties that supported President Sirisena are in agreement on this. The harder problem will be to find a solution to the ethnic conflict that is endorsed by all communities. On this issue the differences between the parties are very great. There is hope that having engaged in a common struggle to regain democracy, they will have developed enough trust and understanding between themselves to reach out to each other and compromise on their differences.

The main post-war failure of the Rajapaksa government in terms of resolving the ethnic conflict was its use of a strong military presence to keep the Tamil people in check rather than to find a mutually acceptable solution that would enable the military to be withdrawn from the Tamil majority areas and restore civilian rule. This failure continued to fuel Sinhalese nationalism that then spilled over into anti- Muslim actions that appeared to have government cover. The memory of how the war against the LTTE ended, and what happened to the Tamil people in its immediate aftermath, continues to be a bitter memory amongst the Tamils. Although the end of the war also saw the end of the large scale human rights violations against them, they continue to feel under threat.

During the last period of Rajapaksa rule, there was also a rise in attacks against the Muslims, their places of religious worship and businesses, which made all the minorities, including Sinhalese Christians, feel insecure. These attacks, often led by 
nationalist Buddhist monks, were accompanied by police inaction. ${ }^{3}$ This smacked of government complicity. The very poor showing of the Buddhist People's Front (BJP), a Buddhist monk-led party at the recently concluded elections shows that the anti-Muslim sentiment of the past few years was not a bottom-up phenomenon, but rather one that was being politically cultivated at higher levels.

Sri Lanka now has a government in which all parties and all communities are represented. The process of decision making will be slow and difficult, but the new government will represent the diversity of Sri Lanka's multi ethnic and multi religious population. In fact the new Sri Lankan government has shown that it is possible to win hearts and minds even after a bloody and costly war. Both in terms of war and peace, what to do and what not to do, Sri Lanka could provide lessons to the international community that is struggling to come to terms with terrorism and its spread.

\section{UN's Report}

The release of the UN Report on alleged war crimes and human rights violations in Sri Lanka's war in September 2015 has been an important step in the country's transition to reconciliation as it requires the government and people to give their attention to the unhealed wounds of the past that continue to fester in the body politic. This report was originally scheduled to be released in March 2015. The investigation team made strong indictments against both the government and LTTE forces for war crimes. The most contentious aspect of the report was its recommendation that the government should "adopt a specific legislation establishing an ad hoc hybrid special court, integrating international judges, prosecutors, lawyers and investigators, mandated to try war crimes and crimes against humanity, with its own independent investigative and prosecuting organ."

The Sri Lankan government requested the UN and members of the UN Human Rights Council to allow it to carry out a domestic judicial probe rather without setting up a hybrid court with international personnel. Public opinion in Sri Lanka amongst the Sinhalese majority is against any international investigation into the past. However, the release of the Report on alleged war crimes and human rights violations in Sri Lanka's war is an important step in the country's transition to reconciliation as it requires the government and people to give their attention to the unhealed wounds of the past that continue to fester in the body politic. It is to be noted that even prior to its release, the government had developed a complex and well thought out mechanism to be led by Sri Lankans. The government announced a mechanism to deal with the past that will be based on a four tier system which will include a Commission for Truth, Justice, Reconciliation, an Office of Missing Persons, a judicial mechanism with special counsel to be set up by statute and an Office of Reparations.

The initial public reaction to the UN war crimes report has been muted. The government asked for a postponement of the release of the report, which was originally scheduled to be released in March of this year. It was because it feared that the political storm it

\footnotetext{
${ }^{3}$ Silent Suppression: Restrictions on Religious Freedoms of Christians 1994-2014, National Christian
} Evangelical Alliance of Sri Lanka, Colombo 2015 
might kick up would be injurious to its electoral prospects at the general elections held in August. The response within the country to the publication of the predecessor UN report on war crimes published in 2011 (the Darusman Report) was highly nationalist. ${ }^{4}$ It was attacked by the then government and its leaders from the day it appeared. The former government and media made it appear that the publication of the Darusman report was a national catastrophe and the people needed to unite behind the government to tackle this threat from the international community.

By way of contrast, the media coverage of the latest UN report in September 2015 has been largely factual and without an overt display of nationalist passion that might have been expected. There has been a description of the contents of the report to inform the general public rather than mobilize them to political action. Initial comments by government leaders and political commentators indicate their sense that the report is not as bad or one-sided as was expected. President Maithripala Sirisena has said that the UN report is a thousand times less damaging than was expected. He has also claimed the political credit for this saying it is due to the improved international image of the country, and the confidence that the international community has in the government.

The government's sober approach to the release of the UN report appears to have induced a similar approach on the part of the general population to the issue of possible war crimes of the past. As a result the space has opened up for rational dialogue within the country as to what needs to be done to heal the past wounds and unite to face the challenges of the future. There is agreement that the past needs to be investigated, and the only question is by whom should it be investigated. There is today a convergence of mind on the part of most people that the truth of the past being ascertained is necessary for the wellbeing of the country. Accordingly, the Sinhalese opposition to the government has been unable to generate immediate resistance to the government's proposals for the dealing with the past.

However, the Tamil polity in Sri Lanka and in the Diaspora is virtually unanimous that the follow up to the report of the UN investigative team should be an international mechanism. They have expressed their rejection of a domestic or Sri Lankan mechanism. Their experience is that the latter mechanisms have never yielded a positive result. Therefore winning the acceptance of the Tamil polity for the Sri Lankan-led mechanisms envisaged by the government is going to prove to be very difficult. The need is for the government to discuss its plans with the Tamil people and their representatives and get their consent to it. The UN Secretary General Ban ki-Moon has welcomed the commitment of the Sri Lankan government to consult all stakeholders in designing the mechanisms to address the issues of the past.

\section{Co-Sponsored Resolution}

By co-sponsoring the resolution on Promoting Reconciliation, Accountability and Human Rights in Sri Lanka the government has taken the initiative with regard to the

\footnotetext{
${ }^{4}$ Report of the Secretary General's Panel of Experts on Accountability in Sri Lanka, UNSG, 31 March 2011 http://www.un.org/News/dh/infocus/Sri_Lanka/POE_Report_Full.pdf
} 
implementation of its recommendations. ${ }^{5}$ Some of the recommendations are controversial. The main controversial recommendation is to set up a judicial accountability mechanism with international participation. But the gain for the government is that it is in charge of the implementation. In addition, for the first time since 2009 when Sri Lanka was taken before the UN Human Rights Council in Geneva, the government succeeded in obtaining the unanimity of the members of the international community represented there regarding Sri Lanka's future.

The resolution of the UN Human Rights Council in October 2015 on promoting reconciliation, accountability and human rights in Sri Lanka affirms "the importance of participation in a Sri Lankan judicial mechanism, including the Special Counsel's office, of Commonwealth and other foreign judges, defense lawyers, and authorized prosecutors and investigators." This was in contrast to the UN Human Rights High Commissioner's Report that called for a hybrid judicial mechanism with the participation of international judges, lawyers, prosecutors and investigators to ensure the credibility of the accountability process. The replacement of the emphasis given to the hybrid judicial mechanism and its replacement with a Sri Lankan judicial mechanism would give the Sri Lankan government a greater measure of credibility in dealing with the nationalist sentiment within the country.

The decision of the UN to call for a hybrid mechanism rather than an international one has been disappointing to those sections of the Tamil polity and civil society who chaff at the repeated failures of Sri Lankan commissions of inquiry and committees to deliver justice. Their expectation was an international investigation which would compel the Sri Lankan government to implement whatever findings were made or possibly face sanctions imposed by the international community. On the other hand, an international investigation may have generated a backlash of Sinhalese nationalism which would have been beneficial to the electorally defeated nationalists who have now been relegated to the opposition to stage a political comeback.

The time table for reporting back to the UN Human Rights Council gives the government a degree of flexibility in getting its implementation mechanisms in order. The government is expected to give its written report on implementation in March 2017, which is 18 months away. At that time the government will have to defend and justify its progress or lack thereof in the implementation of the recommendations to be found in the resolution. Prior to that there will be a continuous assessment made of the implementation of the recommendations by the UN High Commissioner who will also be giving an oral update to the UN Human Rights Council in nine months.

As can be expected the opposition parties took the view that the government gave in to the Western led international community by agreeing to co-sponsor the resolution on Sri Lanka. They have argued that by co-sponsoring the resolution, the government is left with no option but to implement the recommendations which have been imposed on Sri Lanka. The previous government which was led by those who are now in the opposition

${ }^{5}$ UNHRC Resolution (A_HRC_30_L.29) on promoting reconciliation, accountability and human rights in Sri Lanka, October 1, 2015.

http://www.ohchr.org/en/NewsEvents/Pages/DisplayNews.aspx?NewsID=16553\&LangID=E 
argued that the successive resolutions of the UN Human Rights Council were damaging to Sri Lanka's interests. But they could not prevent the resolutions being passed despite their opposition, and each time the resolution was stronger in terms of what was being imposed on the country.

\section{Collaborative Approach}

The previous government's strategy of seeking to defy the United States and other Western countries in the UN Human Rights Council led to three successive defeats for Sri Lanka. By aggressively countering and opposing those countries the previous government also began to internationalize its differences with them. The third resolution of the UN Human Rights Council in June 2014 established an international investigation under the aegis of the UN Human Rights Commissioner that probed the allegations of human rights violations and war crimes in the last phase of the country's war. It had two provisions in it for addressing the issue of accountability for the end phase of the country's three decade long war. First it called on the Sri Lankan government to conduct a credible domestic investigation into the matter. Second, it also made reference to the two previous resolutions that made the same call, and noted that progress was not satisfactory.

However, by co-sponsoring the latest resolution of October 2015, the new Sri Lankan government succeeded in reducing the level of imposition. The government's decision to co-sponsor the resolution on the future its post-war accountability process means that Sri Lanka has the status of an equal partner. The fact of co-sponsorship implies that the Sri Lankan government will be party in charge of implementing the recommendations, and this would be within its sphere of control. The tilting of the balance in favor of Sri Lanka is also reinforced by the reference to a Sri Lankan judicial mechanism in the resolution. The government has announced a mechanism to deal with the past that will be based on four components. It will include a Commission for Truth, Justice, Reconciliation, an Office of Missing Persons, a judicial mechanism with special counsel to be set up by statute and an Office of Reparations.

Sri Lanka's foreign minister Mangala Samaraweera addressing the UNHRC in Geneva laid down the parameters of the government's plan for post-war justice and reparation in the following words ${ }^{6}$ :

"The ideas that the Government has evolved for setting up independent, credible and empowered mechanisms for truth seeking, justice, reparations and guarantees of nonrecurrence within the framework of the Constitution include the following:

-For truth seeking, the establishment by statute, of two mechanisms:

(i) a Commission for Truth, Justice, Reconciliation and Non-recurrence to be evolved in consultation with the relevant authorities of South Africa. This

\footnotetext{
${ }^{6}$ Statement delivered by Mangala Samaraweera, Minister of Foreign Affairs of Sri Lanka at the 30th Session of the UN Human Rights Council, Geneva, on 14 September 2015. http://www.news.lk/fetures/item/9742statement-by-mangala-samaraweera-at-the-30th-session-of-the-unhrc-geneva
} 
mechanism is envisaged as having a dual structure: a 'Compassionate Council' composed of religious dignitaries from all major religions in the country and a structure composed of Commissioners. For many victims of human rights abuses, from whichever community, where the perpetrators are unclear for a judicial mechanism to handle, or where the practices of the state and society have resulted in discrimination, this Commission will allow them to discover the truth, understand what happened and help remedy any sense of injustice.

(ii) an Office on Missing Persons based on the principle of the families' right to know, to be set up by Statute with expertise from the ICRC, and in line with internationally accepted standards.

-On the Right to Justice, what is being proposed is for a Judicial Mechanism with a Special Counsel to be set up by Statute. This takes into account the right of victims to a fair remedy and aims to address the problem of impunity for human rights violations suffered by all communities. There have been previous instances as well in Sri Lanka when criminal justice mechanisms of different kinds have been set up. This, therefore, is not at all an alien concept. Neither is it aimed at a particularly group of persons, but something that is essential in terms of upholding the rule of law, and creating a society that respects the rule of law.

-On the Right to Reparations, an Office for Reparations to be set up by Statute to facilitate the implementation of recommendations relating to reparations made by the proposed Commission on Truth, Justice, Reconciliation and Non-recurrence, the Office of the Missing Persons, the LLRC and any other entity."

However, the Tamil polity in Sri Lanka and in the Diaspora is virtually unanimous that the follow up to the report of the UN investigative team should also be an international mechanism. They completely reject a domestic or Sri Lankan mechanism. Their experience is that the latter mechanisms have never yielded a positive result. Therefore winning the acceptance of the Tamil polity for the domestic mechanisms envisaged by the government is going to prove to be very difficult.

\section{Toned Down}

Due to the new government's cooperative approach, the international community also appears to have tried to tone down the resolution to meet some of the concerns of the Sri Lankan government. An analysis of the resolution by the South Asian Centre for Legal Studies (SACLS) provides a commentary on each paragraph of the solution argues that the US and other co-sponsoring countries "were very keen that the text of the resolution reflect the changes that took place in Sri Lanka after January 2015 (presidential election) and thereafter again in August (general election)." It also noted that the US ambassador in Geneva repeatedly stated that "the resolution should reflect two realities: First the 
change that had happened in Sri Lanka, and second the gravity and seriousness of the violations of human rights and crimes contained in the UN report."

Thus, the resolution noted in a positive manner the passage of the $19^{\text {th }}$ Amendment and its potential contribution to promoting democratic governance, including strengthening judicial independence within the country. It also highlighted the positive steps taken by the government to improve life for the war-affected people of the North and East, and acknowledged the progress made by the government in rebuilding infrastructure, demining, returning land taken over as high security zones and resettling displaced persons. The analysis by SACLS also notes that the drafters of the resolution were also sensitive to phraseology, and gave deference to the Sri Lankan government's preferences. Instead of calling on the UN High Commissioner to monitor the implementation of the recommendations it used the alternative formulation of assessing rather than monitoring.

Now that the session of the UN Human Rights Council in Geneva is over, the government's attention will necessarily have to turn to Sri Lanka. Prime Minister Ranil Wickremesinghe has taken the lead in addressing the country on the contents of the resolution and what it means. He is reported to have met with the top military and police commanders and explained the Geneva process and resolution to them. It will also be necessary to take this message to the larger civil society. This can be done both through NGOs and also government servants who reach vast numbers of the general public. It is largely civil society work that has created a general environment in post-war Sri Lanka that demonstrated a positive resistance to attempts to re-ignite ethnic nationalism within society.

\section{Transitional Justice}

How a nation interacts with its past creates the foundation upon which its future is built. Sri Lanka's thirty-year civil war was characterized by grave human rights violations that have been left unaddressed. It has led to demands both from within the country and internationally for an investigation into war crimes. Transitional justice mechanisms can help form new bonds between people, and between citizens and their government. Transitional justice can be effective tool for reconciliation, political stability and reform. There is a need to identify a viable mechanism that will enable Sri Lankans to come to terms with their past on a mutually accepted basis and to advance the cause of reconciliation. Without a deep understanding of how Sri Lankans view truth, punishment and reconciliation, an effective truth and reconciliation mechanism to build sustainable peace will not be possible. Transitional justice can only be effective and contribute to enduring peace if all perspectives of society are incorporated into the design and implementation of processes.

The question in Sri Lanka now is what transitional justice path will be most accepted and therefore most effective. An option for the Sri Lankan government that may or may not still be on the table would be to consider South Africa assisting in the establishment

\footnotetext{
${ }^{7}$ An analysis of the UNHRC Resolution on Sri Lanka by the South Asian Centre for Legal Studies, Financial Times, October 6, 2016. http://www.ft.lk/article/479397/An-analysis-of-the-UNHRC-Resolution-on-Sri-Lanka
} 
of a Truth and Reconciliation Commission with a mandate to look into the entire phase of armed conflict. Any investigation of the past, either in the form of an international inquiry or a national Truth and Reconciliation Commission would need to win the acceptance of the different ethnic communities who constitute the Sri Lankan people. However, to date, the government has not approached the war-affected communities in an attempt to understand what they need to heal and reconcile with one another. There is a need to gain a fuller understanding of what truth and reconciliation means and what it should look like in Sri Lanka given the needs and desires of the diverse local population whose consent needs to be obtained for sustainable peace and reconciliation.

The resolution that the government co-sponsored in October 2015 stated that the UN High Commissioner would submit an oral update to the Human Rights Council at its thirty-second session (June 2016) and a comprehensive report followed by discussion on the implementation of the present resolution at its thirty-fourth session (March 2017). So far the most important of these governmental actions is the unveiling of the draft legislation on the Office of Missing Persons. This was one of the four transitional justice mechanisms that Foreign Minister Mangala Samaraweera promised to establish in the run up to the co-sponsored resolution of October 2015. Other actions taken by the government in the past month include the setting up of a witness protection unit under the Ministry of Justice, the decision to re-issue Sri Lankan passports to those who had sought political asylum abroad if they so desired, and the release of the report of the Public Representations Committee on constitutional reforms.

This flurry of announcements shows that the government has not been as inactive as it seemed with regard to addressing the controversial issues of transitional justice. An international watchdog group the Sri Lanka Campaign for Peace and Justice has said that "Of the 25 specific commitments pledged by the government at the Human Rights Council last year, 16 can be classified as 'not on track' or as giving cause for concern, compared to only 3 which can be described as 'on track'. For the 6 remaining commitments it remains too soon to say." They have further stated that "there are worrying signals that it is not doing enough to prepare the ground some of the toughest, yet arguably most important, steps - such as de-militarizing the North, investigating disappearances and prosecuting war crimes." 8

The draft legislation on the Office of Missing Persons reflects a considerable amount of thought and research and can be considered as superior to any previous Sri Lankan legislation on the issue. Even those international human rights watchdog groups like Human Rights Watch have been critical of it on the grounds of process rather than substance. They have pointed out that there has been insufficient public discussion about the legislation and that the victims who are to be the beneficiaries should have been consulted. One of the key problems with regard to the government's implementation of the UNHRC resolution is that it is being done without transparency. The sudden emergence of the legislation of the Office of Missing Persons was, however, an indication that the government had been doing its homework but without letting the world-at-large know about it.

\footnotetext{
${ }^{8}$ Holding the government of Sri Lanka to its promises, June 1, 2016

https://www.srilankacampaign.org/holding-government-sri-lanka-promises/
} 


\section{Non-Transparency}

It is likely that a similar behind-the-scenes approach is taking place with regard to the three other mechanisms that the government promised in regard to the UNHRC resolution on which there will be a report back in Geneva. These would be Truth and Reconciliation Commission, the Special Court on accountability and the Office of Reparations. There were news items in the media that government delegations had been visiting countries such as South Africa to study their post-conflict healing and reconciliation processes which is one indication that work is being done on these as well. South Africa, for instance, is the home to the model Truth and Reconciliation Commission that has inspired other countries seeking to strengthen their post-war reconciliation processes.

The government appears to be following a deliberate strategy of non-transparency in dealing with issues of transitional justice at this time. It is aware that this is an issue on which there could be mass mobilization by the opposition that could threaten its stability. The UNHRC came to public prominence in Sri Lanka due to its efforts that began immediately after the end of the war in 2009 to bring the previous government to book on charges of war crimes. This not only provoked furious resistance by the government of the day, but also prejudiced the minds of most Sri Lankans who rejoiced that the war had come to an end. The then government was able to convince most Sri Lankans that the international effort to bring it to book for accountability was actually to punish it for winning the war.

The government's non-transparent approach has meant that despite the passage of time little is known about what the government is doing or plans to do with regard to the transitional justice process. This has deprived the opposition with the ammunition with which to attack the government and has limited their ability to mobilize the general population on the basis of narrow nationalism. The government's strategic approach has given it more time to stabilize itself in dealing with the challenge of the opposition. In the meantime the government is continuing to find new evidence to build up its legal cases against members of the former government who are strongmen in the opposition on corruption and criminal charges.

Ironically the downside of the government's non-transparent approach to the transitional justice process, despite its motivation of ensuring its political viability, is that it has created doubts amongst sections of the international community, as evidenced in the statements issued by Human Rights Watch and the Sri Lanka Campaign for Peace and Justice. It is important that the government should address the concerns of the international community that has been strongly supportive of it after the change of government in January 2015. International goodwill is important not least because significant economic benefits can flow from it. Also, the transitional justice process cannot be a non-transparent one in the longer term, for issues of truth and truth commissions are necessarily public ones that the general population will have to be part of. The secret ingredients notwithstanding, the proof the pudding will be in the eating. 